Rev. Biol. Trop. 52(1): 239-247, 2004

www.ucr.ac.cr www.ots.ac.cr www.ots.duke.edu

\title{
A new species of Dipsas (Squamata: Colubridae) from Guyana
}

Ross D. MacCulloch \& Amy Lathrop

Centre for Biodiversity and Conservation Biology, Royal Ontario Museum, 100 Queen's Park, Toronto, Ontario M5S 2C6, Canada; rossm@rom.on.ca; amyl@rom.on.ca

Received 04-XII-2002. Corrected 09-I-2004. Accepted 12-X-2004.

\begin{abstract}
A new species of Dipsas is described from the Pakaraima Mountains of Guyana. The new species is characterised by 15 dorsal scale rows with the middorsal row slightly enlarged, four pairs of chinshields with the first pair elongate, elongate loreal entering orbit, one preocular, six upper labials, and head narrow anteriorly, increasing in width posteriorly. It could not be determined to which of Peters' (1960) species groups the new species belongs. The new species is known only from $1490 \mathrm{~m}$ elevation on Mount Ayanganna, a tepui in the Guiana Shield, where it was found in high-tepui low-canopy habitat, in bromeliads or branches. This is the first record of Dipsas as a member of the Guiana Shield high-tepui herpetofauna.
\end{abstract}

Key words: Colubridae, Dipsas, new species, Guyana, Pakaraima Mountains, tepuis.

Dipsadine snakes constitute a morphologically unique group of the Neotropical Colubridae. The members of this group exhibit a number of characters specialised for an arboreal malacophagous life such as lateral compression of the body, reduction or loss of the mental groove and inward angling of the maxillary teeth.

The most recent thorough review of the genus Dipsas Laurenti 1768 was by Peters (1960), who recognized 32 species, and divided them into seven species groups based primarily on colour pattern. Peters and Orejas-Miranda (1970) revised the genus to 28 species. More recently, a new species of Dipsas from Bolivia was described by Reynolds and Foster (1992). Mexican species of Dipsas were examined by Kofron (1982), and Costa Rican species were reviewed by Savage (2002).

Of the 29 species of Dipsas, most occur in Central America or Andean South America. Five species $(D$. catesbyi, D. copei, $D$. indica, $D$. pavonina and $D$. variegata), as well as the dipsadine Sibon nebulata, occur in the Guiana region of northeastern South America (Peters 1960, Roze 1966, Peters and Orejas-Miranda 1970, Chippaux 1986, Starace 1998, Kornacker 1999).

Recent collections from Mount Ayanganna, in the Pakaraima mountains of western Guyana, included specimens of a new species of Dipsas.

\section{MATERIALS AND METHODS}

Collecting activities were concentrated on the northeast plateau of Mount Ayanganna $\left(05^{\circ} 24^{\prime} \mathrm{N}, 059^{\circ} 57^{\prime} \mathrm{W}\right)$, at an elevation of 1490 $\mathrm{m}$. Mount Ayanganna is one of the easternmost tepuis in the highlands of the Guiana Shield. The habitat was described in MacCulloch and Lathrop (2001, 2002). Specimens were euthanized by injection with sodium pentobarbitol, and then fixed in formalin, while tissue (liver) was removed and preserved in 95\% ethanol. Specimens were compared with published 
descriptions or museum specimens (Appendix). Descriptions follow the format used by Peters (1960) to facilitate intrageneric comparisons. Scale reductions are expressed using the method devised by Dowling (1951), as modified by Peters (1960). Hemipenes are described using terminology established by Dowling and Savage (1960). Dentition was determined from x-rays of specimens.

All specimens of the species described herein are in the collections of the Royal Ontario Museum (ROM).

\section{DESCRIPTION}

\section{Dipsas pakaraima sp. nov.} (Figs. 1, 2, 3)

Holotype: ROM 41233, adult male collected on the northeast plateau of Mount Ayanganna, Guyana, 05²4'N, 05957' W, elevation 1490 m, 31 October 2000, by Roland Edward.

Paratypes: ROM 41234-6, three adult males and ROM 41237, a female, collected in the vicinity of the type-locality, 26-31 October 2000, by Amy Lathrop, Carter Cox and Ross MacCulloch.

Diagnosis: A member of the genus Dipsas characterised by 15 dorsal scale rows, the middorsal row slightly enlarged; four pairs of chinshields, the first pair elongate; elongate loreal entering orbit; one preocular; six upper labials, with only one elongate upper labial posterior to those that enter the orbit; head narrow anteriorly, increasing in width posteriorly; eye visible from below.

The new species can be referred to Dipsas because it possesses the following suite of characters: head distinct from neck; mental groove absent; tertiary temporals present; four pairs chinshields; posterior chinshields separated from lower labials by other scales; maxillary teeth angled inwards; pterygoids parallel, not diverging posteriorly; occurring in northern South America (Peters 1960).
Dipsas pakaraima can be distinguished from $D$. catesbyi by its 15 dorsal scale rows (13 in D. catesbyi), six upper labials (8-9), loreal entering orbit (not); from $D$. copei by four pairs of chinshields (three in $D$. copei), six upper labials (10-11), loreal entering orbit (not); from $D$. indica and $D$. pavonina by 15 scale rows (13 in D. indica and D. pavonina), six upper labials (9-11), four pairs of chinshields (three); from $D$. variegata by one preocular (none in D. variegata), six upper labials (7-10), four pairs of chinshields (two or three). No other described species of Dipsas occurs in the Guiana region.

Description of holotype: Rostral as broad as long, visible from above; internasals wider than long, much smaller than prefrontals; prefrontals pentagonal, as wide as long; frontal bell-shaped, 1.3 times as long as wide; supraoculars 1; parietals 1.4 times as long as wide; occipital region with three transverse rows of scales (Fig. 1, top).

Nasal partially divided dorsally; loreal elongate, in contact with nasal, prefrontal, preocular, 2nd, 3rd and 4th labials, enters orbit; preocular 1, narrowly in contact with frontal; suboculars absent; postoculars 1; primary temporal 1 , enters orbit; secondary temporals 2 ; tertiary temporals 2; upper labials 6, 4th and 5th entering orbit, 6th longest. Pupil vertical (Fig. 1, centre).

Lower labials 8, first pair in contact behind mental, 4 pairs in contact with first pair of chinshields; 4 pairs of chinshields, the first elongate, crescent-shaped, the second in contact with 4th and 5th labials, the third and fourth separated from labials. Ventral headscales with pores scattered across the surface of the scales. Mental groove absent (Fig. 1, bottom).

Head narrow anteriorly, widest at temporal region, maximum width $55 \%$ of length. Maxillary teeth 17; palatine teeth 9; pterygoid teeth 7. Snout-vent length $435 \mathrm{~mm}$, tail $190 \mathrm{~mm}$.

Ventrals 191; anal entire; subcaudals 117. Dorsal scale rows 15, vertebral scale row slightly enlarged, 1.1 times the width of the paravertebral scales at midbody, vertebral scales blunt-tipped. Scales without apical pits. 

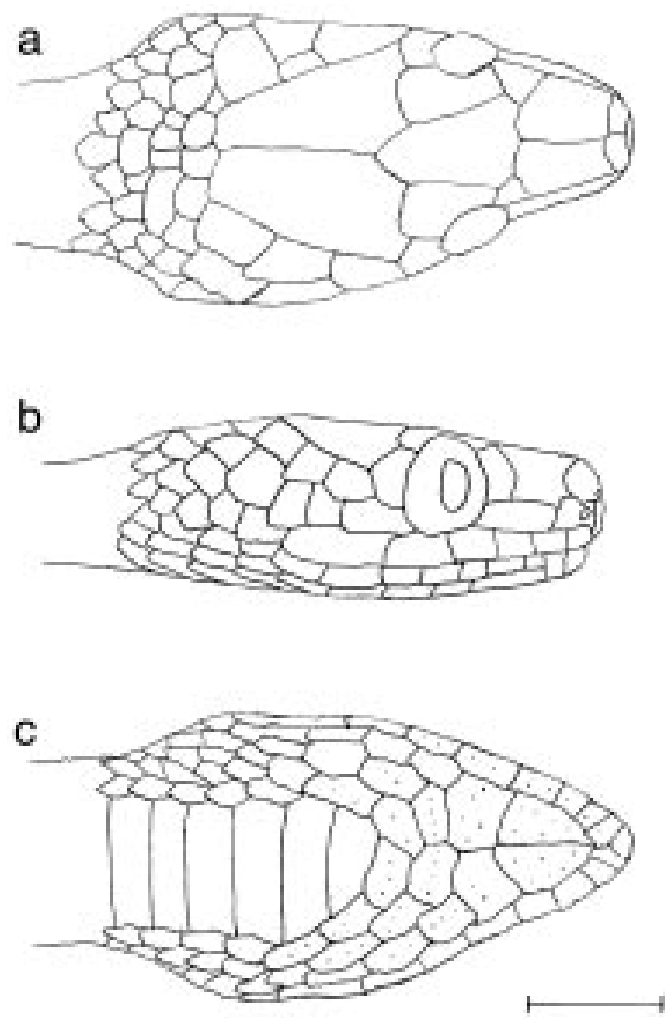

Fig. 1. Head of Dipsas pakaraima holotype: top, dorsal view; centre, lateral view; bottom, ventral view. Scale bar $=5 \mathrm{~mm}$.

Dorsal scale reduction formula $173+4$ (6) 15 -8 (189) 14 7+7 (191) 13. Caudo-dorsal scale reduction formula $61+2$ (12) $41+2$ (76) 2 (117).

Hemipenial Morphology: The hemipenis is single, slightly wider at apex, capitate. The everted organ is five subcaudals or $8 \mathrm{~mm}$ in length. The demarcation of the capitate region is evident on both the sulcate and asulcate sides, at about the level of the third subcaudal. The capitate region is covered in spines which decrease slightly in size distally. On the sulcate side, the midsection has spinose longitudinal plicae, the spines increasing in size distally. The capitate region has a patch of large spines medially with smaller spines laterally and distally. Asulcate midsection with spinose plicae laterally and basally; capitate region with larg- er spines medially, decreasing in size distally. Basal section plicate, naked but for a few small spinules. The sulcus spermaticus bifurcates near the apex. The intrasulcar surface is smooth. Hemipenes and adjacent tissue are white. (Fig. 2).

Colour in life: Dorsolateral ground colour light brown anteriorly, darkening posteriorly. A series of 22 pairs of medium brown dorsolateral blotches, outlined in black, between neck and vent. Anteriorly the blotches are each about five scales long middorsally, lengthening to 8-9 scales dorsolaterally, then tapering to five scales on the first dorsal scale row. Posteriorly the blotches become shorter. Anteriorly the blotches are separated by one or two lateral scales; toward midbody this separation diminishes, and the black borders of adjacent blotches are in contact. In the five posteriormost blotches the black borders are reduced laterally, present only middorsally and on the ventrals. This results in a continuous uniform medium brown lateral colouration.

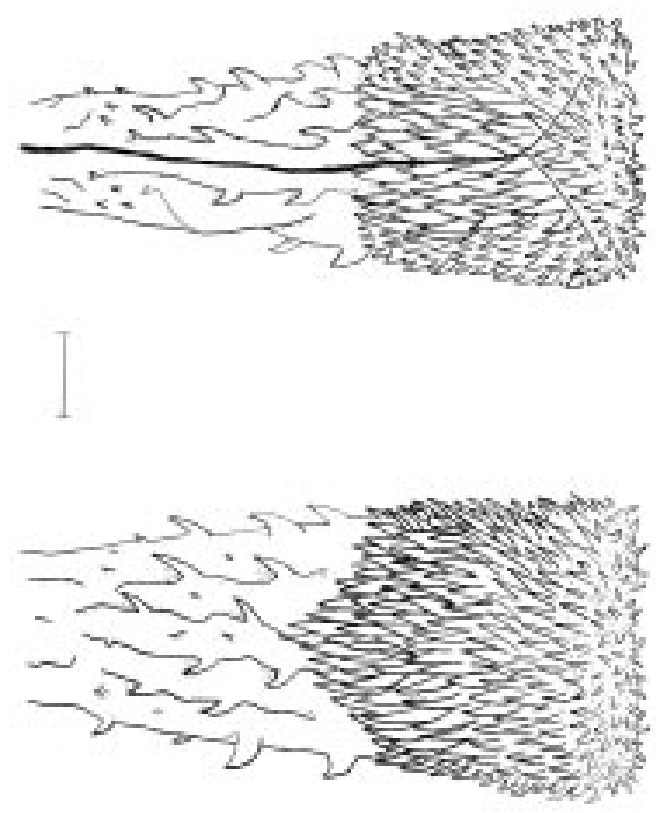

Fig. 2. Hemipenis of Dipsas pakaraima holotype, left organ. Sulcate side (top) and asulcate side (bottom). Scale bar $=1 \mathrm{~mm}$. 
Many pairs of blotches are not exactly opposite or symmetrical but rather alternating, creating a pattern of staggered blotches along the back. This asymmetry is caused by a blotch being a different length from its corresponding opposite blotch. In the holotype the blotch pairs change from opposite to alternating to opposite twice along the length of the body (Fig. 3).

Within the dorsal blotches the scales appear to have dark tips, the result of overlapping the next posterior scale. However, the lightercoloured scales outside the blotches do not appear dark-tipped where they overlap the next scale. Between the blotches the light brown background creates a middorsal pattern of diamond shapes (or half-diamond where the blotches are not symmetrical); these diamonds contain small dark brown spots. The dorsal background colour becomes progressively darker posteriorly, converging with the blotch colour.

Ventral background colour pale brown, the dorsolateral blotches extending to the midventral point, each covering two or three ventrals. Ventrals otherwise immaculate anteriorly, posteriorly with small black patches consisting of several juxtaposed or narrowly separated squarish to half-moon-shaped marks. The ventral dark markings become more intense posteriorly (Fig. 3).

Tail with a narrow cream middorsal stripe flanked by narrow black stripes. Background colour is dark brown laterally and ventrally, with a few small cream-and-black lateral blotches proximally.

Head dark brown dorsally and laterally. Lower labials with a narrow white band at lip. Chin medium brown with light brown mottling increasing posteriorly. In preservative the colour has changed only slightly.

Variation: The male paratypes vary in SVL from 381-557 $\mathrm{mm}$ and in tail length from 158-237 mm. The single female has a SVL of $375 \mathrm{~mm}$ and tail length of $157 \mathrm{~mm}$.

There is considerable variation in scale counts, as is often encountered in Dipsas (Peters 1956, 1960). Among the males ventrals range from 178-193, subcaudals 103-117. The longest male has the fewest subcaudals and the second-fewest ventrals, while the shortest male has the most ventrals. The female has 175 ventrals and 98 subcaudals. There was no correlation between SVL and number of ventrals, subcaudals, blotches or maxillary teeth among the males (Table 1).

Other than the holotype, only one male (ROM 41234) has scale row reduction anterior to the anus. This specimen has 178 ventrals and a reduction formula of $15-8$ (175) 14 7+7 (177) 13. In two males and the female, the neck reduction involves rows four and five instead of rows three and four. Among the males the caudo-dorsal scale reduction formula is $61+2(12-18) 41+2$ (54-82) 2 (103-117). Caudo-dorsal scale row reduction is $1+2$ in all males, but is $2+3$ in the female, and occurs closer to the vent. The female's caudo-dorsal scale reduction formula is $62+3$ (7) $41+2$ (60) 298.

The smallest male has two postoculars, so the primary temporal does not enter the orbit. This male also has the most temporals, $3+3+3$. The female has fused temporals on both sides, creating a temporal formula of (left/right) $1+1+3 / 1+1+2$. The female has only three pairs of chinshields and lacks pores on the ventral

TABLE 1

Meristic Counts of Dipsas pakaraima

\begin{tabular}{|c|c|c|c|c|c|c|c|}
\hline Catalogue Number & Sex & $\mathrm{SVL}(\mathrm{mm})$ & $\mathrm{TL}(\mathrm{mm})$ & Ventrals & Subcaudals & Dorsal Blotches & Maxillary Teeth \\
\hline 41233 & M & 435 & 190 & 191 & 117 & 22 & 17 \\
\hline 41234 & M & 465 & 216 & 178 & 106 & 32 & 16 \\
\hline 41235 & M & 381 & 158 & 193 & 111 & 31 & 20 \\
\hline 41236 & M & 557 & 237 & 190 & 103 & 27 & 17 \\
\hline 41237 & $\mathrm{~F}$ & 375 & 157 & 175 & 98 & 27 & 15 \\
\hline
\end{tabular}



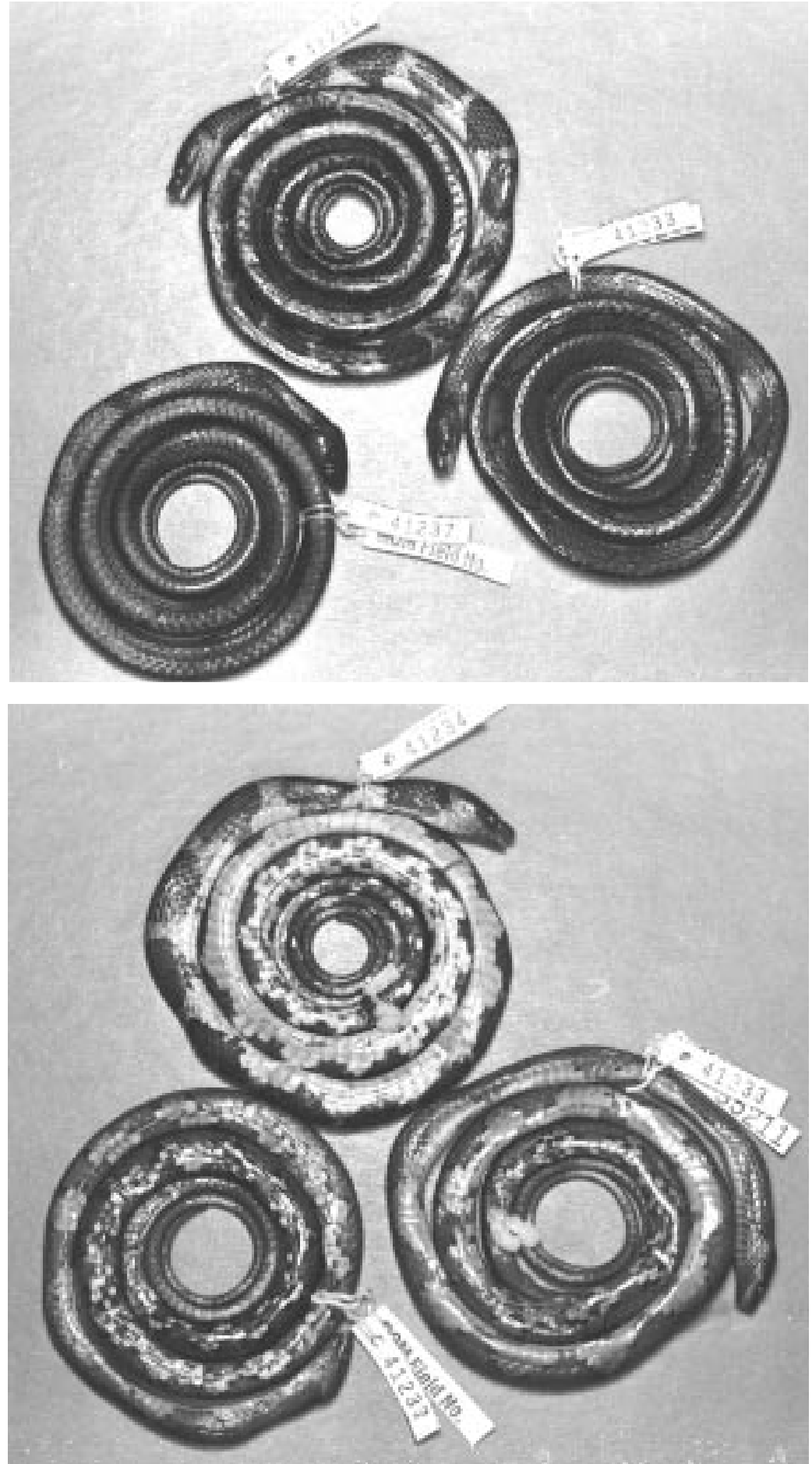

Fig. 3. Colour pattern variation in Dipsas pakaraima. Dorsal view (above) and ventral view (below). Top: ROM 41234, male, 465 mm SVL; lower left: ROM 41237, female, $375 \mathrm{~mm}$ SVL; lower right: holotype, male, $435 \mathrm{~mm}$ SVL. 
head scales. One male has a few divided ventral scales, of types 1 and 6 of Peters (1960).

Maxillary teeth are 16-20 in males, 15 in the female (Table 1). Palatine teeth are 7-8 in males, five in the female. Pterygoid teeth are 7-9 in males, six in the female.

Colour variation: The dorsal background colour varies from light brown to cream, and the blotches range from medium brown to very dark brown (Fig. 3). In most paratypes the majority of the dorsal blotches are symmetrically paired, but all exhibit a pattern of alternating blotches or asymmetry at some point along the body. Asymmetry is caused by a blotch being a different length from its corresponding opposite blotch. In some individuals the blotches change from symmetrical pairing to asymmetrical (alternating) and back again, along the length of the body, sometimes more than once. In all paratypes the blotches become progressively shorter posteriorly, from 6-7 to 4-5 scales in length. In all individuals the dorsal and ventral background colour becomes progressively darker posteriorly, and the tail pattern is much less obvious than the body pattern. Peters (1960) found that older individuals exhibited less colour contrast, but there was no correlation between size and colour contrast among the four males of $D$. pakaraima.

In the female the blotches are apparent ventrally and laterally, but much less apparent on the upper part of the body, so that the middorsal colouration appears uniformly medium brown (Fig. 3). This specimen has 27 body blotches; its tail has only a few midventral traces of blotches proximally, and is otherwise immaculate medium brown.

Etymology: The specific epithet refers to the Pakaraima Mountains of western Guyana, where the type locality is located. It is used as a noun in apposition.

Distribution: Dipsas pakaraima is known only from the type locality, Mount Ayanganna, Guyana.

Natural History: All specimens were collected on the northeast plateau of Mount Ayanganna $\left(05^{\circ} 24^{\prime} \mathrm{N}, 059^{\circ} 57^{\prime} \mathrm{W}\right)$, in the Pakaraima Range of western Guyana. Mount
Ayanganna is one of the easternmost tepuis in the Guiana Shield. The specimens were collected at $1490 \mathrm{~m}$, in wet, low, evergreen hightepui forest. The vegetation was described by Fanshawe (1952), Maguire (1970), and Huber et al. (1995), and a checklist is available at www.mnh.si.edu/biodiversity/bdg/. All specimens were collected at night, and all were in large terrestrial bromeliads (Brocchinia) or on low branches (0.5-2 m height). Stomachs contained no identifiable remains of prey. All individuals have some abdominal fat deposits. The female's ovaries have no enlarged follicles.

Single individuals of two other colubrid species, Dipsas variegata and Liophis miliaris, were also collected on the plateau.

\section{DISCUSSION}

Relationships: Peters (1960) separated Dipsas into seven species groups based primarily on colour pattern, although some squamation characters were also used. The catesbyi group has 13 scale rows, the loreal seldom enters the orbit and in some species the head narrows anteriorly. The oreas group has 15 scale rows, and some have four chinshields. Some members of the pratti group (eg. D. latifrontalis) have four chinshields. The variegata group has 15 scale rows, 3 pairs of chinshields, and no loreal. The indica group has three pairs of chinshields, 13 scale rows, one preocular plus loreal entering orbit, and no teeth on the pterygoid.

Dipsas pakaraima cannot be assigned to any existing species group because it does not match the characters of any one group. It resembles the catesbyi group in colour pattern, but has three squamation characters in common with D. elegans (oreas group); long loreal, first pair of chinshields slightly elongate, temporals $2+2 / 3+3$. Some characters of Guiana Shield species of Dipsas are summarised in Table 2.

Zoogeography: Although some of the Andean species of Dipsas occur at high elevations, there have been no previous reports of 
TABLE 2

Comparative Characters of Dipsas occurring in the Guiana Shield region

$\begin{array}{lcccccc}\text { Species } & \text { D. pakaraima } & \text { D. catesbyi } & \text { D. copei } & \text { D. indica } & \text { D. pavonina } & \text { D. variegata } \\ \text { Scale Rows } & & & & & & \\ \text { Chinshields } & 15 & 13 & 15 & 13 & 13 & 15 \\ \text { Preoculars } & 4 & 4 & 3 & 3 & 3 & 2-3 \\ \text { Loreal enters orbit } & 1 & 1 & 1 & 1 & 1 & 0 \\ & \text { yes } & \text { no } & \text { no } & \text { yes } & \text { yes } & \text { yes }\end{array}$

Dipsas from the Guiana Shield tepuis (Roze 1958a, b, 1966, Donnelly and Myers 1991, Myers 1997, Myers and Donnelly 1996, 1997, 2001, Gorzula and Señaris 1999). In addition to Dipsas pakaraima, one D. variegata, a female, was also collected at $1490 \mathrm{~m}$ on Mt. Ayanganna. The highest reported elevations for the latter species have been $300 \mathrm{~m}$ (Gorzula and Señaris 1999) and $500 \mathrm{~m}$ (Roze 1966), in Venezuela. The only other snake collected on Mt. Ayanganna at $1490 \mathrm{~m}$ was a male Liophis miliaris. Several other snakes (Chironius fuscus, Oxyrhopus trigeminus, Bothrops atrox) were encountered at the base of the mountain, at $800-850 \mathrm{~m}$ elevation.

Dipsas is not a common tepui colubrid genus, unlike Thamnodynastes, which has been found on several Venezuelan tepuis (Gorzula and Ayarzagüena 1996, Myers and Donnelly 1996, 1997, 2001, Gorzula and Señaris 1999). The presence of D. pakaraima on Ayanganna, but not on other tepuis, does not support the pantepui theory of Guiana Shield zoogeography. Rather, it appears that the ancestor of D. pakaraima invaded Ayanganna from the surrounding lowland, and its presence supports the "lowland invader" hypothesis of tepui faunas. This is further supported by the sympatric presence of the lowland species D. variegata and Liophis miliaris. Myers (1997) and Myers and Donnelly (2001) found little overlap between the fauna of neighbouring Guiana tepuis; these findings, combined with the results of this paper, indicate that opportunistic colonization of the region's highlands by lowland taxa is commonplace, and that tepui herpetofaunas are composed of the descendants of both pantepui and lowland ancestors.

\section{ACKNOWLEDGMENTS}

Specimens were collected and exported under permits issued by the Guyana Environmental Protection Agency. The field assistance of Lancelot George, Roland Edward, and especially Carter Cox was greatly appreciated. We thank R. Reynolds and S. Gotte (USNM) for loans of or access to specimens. We also thank V. Funk, C. Kelloff, M. Tamessar, D. Naraine, C. Mendonca, and Fr. C.L. Roland. B. Morera and three reviewers provided valuable comments on an earlier version. This study was funded by grants from the Royal Ontario Museum Foundation, the ROM Centre for Biodiversity and Conservation Biology, and a Smithsonian BDG Fellowship to RDM. This is contribution 260 of the Centre for Biodiversity and Conservation Biology, ROM and number 99 in the Smithsonian's Biological Diversity of the Guianas Program publication series.

\section{RESUMEN}

Se describe una nueva especie del género Dipsas de las montañas Pakaraima de Guyana. Esta se caracteriza por presentar 15 hileras de escamas dorsales con las escamas de la hilera vertebral ligeramente agrandadas, cuatro pares de escudos geneiales con el primer par elongado, loreal elongado y en contacto con la órbita, una escama preocular, seis labiales superiores y la cabeza angosta en la partie anterior y más ancha posteriormente. No se determino su ubicación de acuerdo a los grupos de especies de Peters (1960). La nueva especie solo es conocida a 1490 m.s.n.m. en el monte Ayanganna, un tepuy del Escudo Guayanés, en bosque de baja altura, dentro de bromelias o sobre ramas. Es el primer informe del género Dipsas como miembro de la fauna altotepuyana del Escudo Guayanés. 


\section{REFERENCES}

Chippaux, J.-P. 1986. Les serpents de la Guyane française. ORSTOM Faune Tropical \#27, Paris. 165 p.

Donnelly, M.A. \& C.W. Myers. 1991. Herpetological results of the 1990 Venezuelan expedition to the summit of Cerro Guaiquinima, with new tepui reptiles. Amer. Mus. Novit. 3017: 1-54.

Dowling, H.G. 1951. A proposed method of expressing scale reductions in snakes. Copeia 1951(2): 131-134.

Dowling, H.G. \& J.M. Savage. 1960. A guide to the snake hemipenis: a survey of basic structure and systematic characteristics. Zoologica 45: 17-28.

Fanshawe, D.B. 1952. The vegetation of British Guiana: a preliminary review. Inst. Paper \#29, Imperial Forestry Inst., Oxford. 96 p.

Gorzula, S. \& J. Ayarzagüena. "1995” [1996]. Dos nuevas especies del genero Thamnodynastes (Serpentes: Colubridae) de los tepuyes de la Guayana Venezolana. Publ. Asoc. Amigos de Doñana 6: 1-17.

Gorzula, S. \& J.C. Señaris. "1998” [1999]. Contribution to the herpetofauna of the Venezuelan Guayana I. A data base. Scientia Guaianae \#8, Caracas. xviii + 270 + 32 p.

Huber, O., G. Gharbarran \& V. Funk. 1995. Vegetation map of Guyana. Centre for the Study of Biological Diversity, Univ. of Guyana, Georgetown.

Kofron, C.P. 1982. A review of the Mexican snail-eating snakes, Dipsas brevifacies and Dipsas gaigae. J. Herpetol. 16: 270-286.

Kornacker, P.M. 1999. Checklist and key to the snakes of Venezuela. Pako-Verlag, Rheinbach. 269 p.

MacCulloch, R.D. \& A. Lathrop. 2001. A new species of Arthrosaura (Sauria: Teiidae) from the highlands of Guyana. Carib. J. Sci. 37: 174-181.

MacCulloch, R.D. \& A. Lathrop. 2002. Exceptional diversity of Stefania (Anura: Hylidae) on Mount Ayanganna, Guyana: three new species and new distribution records. Herpetologica 58: 327-346.

Maguire, B. 1970. On the flora of the Guyana highland. Biotropica 2: 85-100.

Myers, C.W. 1997. Preliminary remarks on the summit herpetofauna of Auyantepui, eastern Venezuela. Acta Terramaris 10: 1-8.
Myers, C.W. \& M.A. Donnelly. 1996. A new herpetofauna from Cerro Yavi, Venezuela: first results of the Robert G. Goelet American Museum - Terramar expedition to the northwest tepuis. Amer. Mus. Novit. 3172: 1-56.

Myers, C.W. \& M.A. Donnelly. 1997. A tepui herpetofauna on a granitic mountain (Tamacuari) in the borderland between Venezuela and Brazil: report from the Phipps Tapirapeco expedition. Amer. Mus. Novit. 3213: 1-71.

Myers, C.W. \& M.A. Donnelly. 2001. Herpetofauna of the Yutaje-Corocoro massif, Venezuela: second report from the Robert G. Goelet American Museum Terramar expedition to the northwestern tepuis. Bull. Amer. Mus. Nat. Hist. 261: 1-85.

Peters, J.A. 1956. An analysis of variation in a South American snake, Catesby's snail-sucker (Dipsas catesbyi Sentzen). Amer. Mus. Novit. 1783: 1-41.

Peters, J.A. 1960. The snakes of the subfamily Dipsadinae. Misc. Pub. Mus. Zool. Univ. Michigan 114: 1-224.

Peters, J.A. \& B. Orejas-Miranda. 1970. Catalogue of the neotropical squamata. Part I. Snakes. U.S. Nat. Mus. Bull. 297: 1-347.

Reynolds, R.P. \& M.S. Foster. 1992. Four new species of frogs and one new species of snake from the Chapare region of Bolivia, with notes on other species. Herpetol. Monogr. 6: 83-104.

Roze, J.A. 1958a. Los reptiles del Auyantepui, Venezuela, basandose en las colecciones de las expediciónes de Phelps-Tate, del American Museum of Natural History, 1937-1938, y de la Universidad Central de Venezuela, 1956. Acta Biol. Venez. 2: 243-270.

Roze, J.A. 1958b. Los reptiles de Chimanta tepui (Estado Bolivar) Venezuela, colectados por la expedición botanica del Chicago Natural History Museum. Acta Biol. Venez. 2: 299-314.

Roze, J.A. 1966. La taxonomía y zoogeografía de los ofidios de Venezuela. Univ. Central de Venezuela, Caracas. 362 p.

Savage, J.M. 2002. The Amphibians and Retiles of Costa Rica: a herpetofauna between two continents, between two seas. University of Chicago. pp. 596599.

Starace, F. 1998. Guide des serpents et amphisbènes de Guyane. Ibis Rouge, Paris. 449 p. 


\section{APPENDIX}

\section{Specimens examined}

Dipsas albifrons (1).

Dipsas catesbyi (2).

Dipsas copei (1).

Dipsas elegans (2).

Dipsas gracilis (2).

Dipsas indica (3).

Dipsas latifrontalis (2).

Dipsas oreas (1).

Dipsas pavonina (2).

Dipsas peruana (2).

Dipsas variegata (2).

Dipsas vermiculata (1). Sibon dimidiata (3). Sibon nebulata (5).

Sibynomorphus turgidus (2).
BRAZIL, Sao Paolo, Presidente Penna, USNM 79356

GUYANA, Bartica, USNM 200509-10

GUYANA, Paramakatoi, ROM 28371

ECUADOR, Pichincha, Pacto, USNM 210937; Nanegal, USNM 210936

ECUADOR, Esmereldas, Santo Domingo, USNM 210945; Guayas, Guayaquil, USNM 210947

PERU, Amazonas, Tseasim, USNM 316598; Huampami, USNM 316597; BRAZIL, Rio de Janeiro, Teresopolis, USNM 208671

ECUADOR, Napo, Borja, USNM 210957, 210959

ECUADOR, Guayas, Guayaquil, USNM 62799

ECUADOR, Napo, Loreto, USNM 210967-8

PERU, Puno, Ollachea, USNM 299232-3

GUYANA, Baramita, USNM 535807; Mount Ayanganna, ROM 39440

PERU, Amazonas, Huampami, USNM 316600

HONDURAS, Copan, Quebrada Grande, ROM 19987-9

TRINIDAD AND TOBAGO, St. George, Blanchisseuse, ROM 17085; BELIZE, Orange Walk, Lamanai, ROM 12789; GUYANA, Paramakatoi, ROM 28373; Mabaruma, USNM 164202; McKenzie, USNM 84524

ARGENTINA, La Rioja, Patquia, USNM 73488, 73492

Sibynomorphus ventrimaculatus (1).PARAGUAY, Itapua, El Tirol, USNM 253571 
